\title{
Belleville rouge, Belleville noir, Belleville rose: The Complex Identity of a Parisian quartier
}

\author{
Carolyn Stott, University of Sydney
}

'Belleville est la Géographie résignée à l'Histoire: la manufacture des nostalgies’ (Pennac 1989: 401) ${ }^{1}$

\section{Introduction}

Perched on a hill overlooking the French capital to its North East, Belleville straddles four Parisian arrondissements: the tenth, eleventh, nineteenth and twentieth (see figures 1 and 2). ${ }^{2}$ While historians and locals often differ on its geographical boundaries, they do agree that the quartier has long been considered a melting pot of cultures and ethnicities. The international street signage and outward appearance of the Bellevillois inhabitants are testimony to the multitude of languages they speak (more than 80, by some accounts). The curious juxtaposition of old, new and partially renovated buildings evokes a long and tumultuous history. The sheer diversity of the population and its numerous artistic workshops uphold Belleville’s reputation as a rich cultural centre. If its culture is widely accepted as rich, the same cannot be said of its economic status; although the suburb has been undergoing a kind of gentrification since the end of the twentieth century, the classification of Belleville as one of the cheapest quartiers on the French Monopoly board still holds true for many

\footnotetext{
1 'In Belleville, Geography has surrendered to History: the construction of nostalgic memories.' My translation; all translations in this essay are mine.

${ }^{2}$ Paris is divided into twenty administrative districts called arrondissements, each of which is subdivided into four quartiers (see Figures 1 and 2).
} 


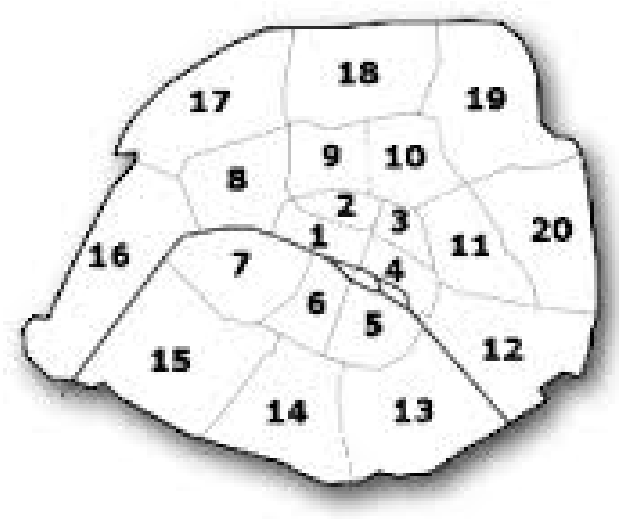

Figure 1: Map of the twenty arrondissements that comprise inner Paris (Belleville is located in the northwestern corner of the twentieth arrondissement, but also spills into the nineteenth, eleventh and tenth arrondissements. Courtesy of Aude Baron [http://www.resto-de-paris.com/wpcontent/uploads/2011/11/paris-arrondissement.png].

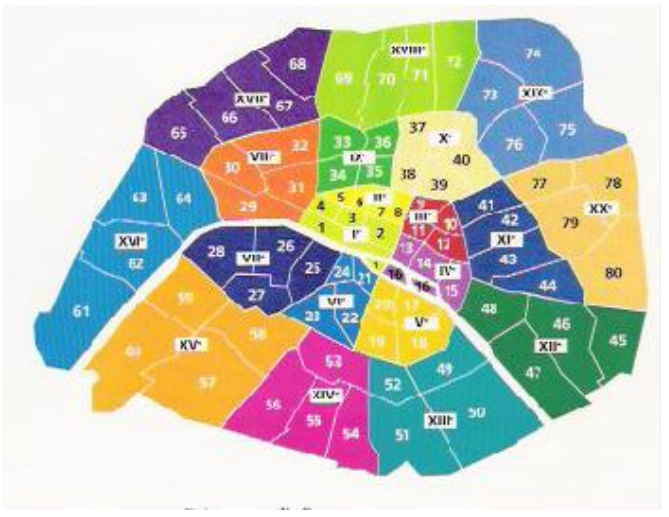

Figure 2: Map of inner Paris showing division of arrondissements into quartiers (Belleville is quartier no. 77). Courtesy of Daniel Freeman [http://www.paris-walking-tours.com/images/quartier.jpg].

Parisians. ${ }^{3}$ Despite this lowly ranking, the quartier attained new prominence as a utopian space during the 1990s, principally due to the phenomenal success of Daniel Pennac’s series of Malaussène novels (1985-1995).

Belleville is not merely a physical space. As Pennac has observed, the mere mention of its name inspires strong feelings, notably a kind of nostalgia for a communal existence perceived as much warmer than that experienced by some contemporary inhabitants of the quartier. ${ }^{4}$ Geography and history join forces; reality and representation become

\footnotetext{
${ }^{3}$ La Goutte d'Or (eighteenth arrondissement), to cite another example, is now one of the cheapest residential quartiers in inner Paris (Kupferman 2013).

${ }^{4}$ See, for example, former Bellevillois resident and author Thierry Jonquet's Jours tranquilles à Belleville (2003).
} 
entangled to the extent that, for literary commentators like Pennac, the presence of a mythological Belleville is evident in the streets and buildings of the actual suburb. Belleville is a place but at the same time an idea of a place that has been created over a number of centuries. Little surprise, then, that this inner Parisian quartier is so difficult to situate geographically or to confine to its current administrative limits. Placing with some degree of accuracy any community of historical significance in a clearly delineated modern topographical setting is a complex task, made even more difficult by the gradual transformation of both the physical space and the population. The variety of representations offered by writers and others claiming some degree of expertise with regard to the quartier of Belleville has created over time a rich and multi-layered palimpsest of identities.

The French term quartier has been retained in this article as it is difficult to translate comprehensively into English. The term's interpretation by sociologists such as Patrick Simon incorporates a quartier's uniqueness as a living space never quite corresponding to official administrative limits; this is particularly true of Belleville, according to Simon (1992: 48). Historians like Gérard Jacquemet agree that 'the symbolic force of the quartier [of Belleville] is so great that it surpasses its [geographical] limits' (1984: 19). In the Parisian landscape, Belleville embodies this definition of a unique space with a personality and history with which its inhabitants identify strongly. The quartier of concern in this article thus fits Marc Augé's notion of an anthropological place, which he describes as 'relational, historical and concerned with identity' (1995: 77).

\section{Background and context}

An understanding of the geographical transformations before and after Belleville's annexation to Paris in 1860, as well as the cultural and physical metamorphosis of the quartier, which occurred predominantly throughout the twentieth century, will give the context necessary for discussing the complex identities that are associated with contemporary Belleville.

Throughout its transformation from Merovingian royal estate to Carolingian hamlet, late medieval village and then sixteenth century parish, pre-revolutionary Belleville remained sparsely populated and rural. In 1789, Belleville became a sizeable commune, capital of the canton Pantin in the department of Seine, in line with the divisions introduced by the new Republic. The next major administrative redefinition of Paris 
nearly a century later was to have a dramatic effect on Belleville. With the annexation of a number of communes surrounding the French capital in 1860, including Belleville, eight new arrondissements were created, incorporating thirty-two new quartiers. Belleville's change in status from a large independent provincial city to one of eighty Parisian quartiers was to have immediate and far-reaching effects on its population, not the least of which included its relegation from second largest city in the department of Seine and thirteenth largest in France, to a minor subdivision of the French capital. The former commune of Belleville was divided into two, in a deliberate but ultimately unsuccessful attempt to curb the increasingly dissident Bellevillois inhabitants, as demonstrated by their active participation in the Paris Commune ten years later. In line with the new rules requiring four quartiers per arrondissement, Belleville became the seventy-seventh quartier of Ménilmontant (see Figure 2). The four main routes of boulevard de Belleville and rues de Belleville, de Ménilmontant and Pixérécourt were established as, and remain to this day, the official boundaries.

As the current administrative boundaries do not correspond to the more extended preannexation Belleville, historians, writers and other interested parties have been trying to realign them ever since. This accounts for the often-cited symbolic overflow of Belleville from the twentieth into the tenth, eleventh and nineteenth arrondissements, incorporating the geographical boundaries of the old commune. The situation was complicated further by the creation in 2002 of 122 conseils de quartier in Paris. The eastern border of Belleville’s conseil de quartier, rue des Pyrénées, reduces slightly the size of the quartier's official administrative limits which date back to Belleville's annexation to Paris. However, to compensate for the reduction in size of the quartier, the appearance in the list of conseils de quartier of Belleville/Saint-Maur in the eleventh arrondissement and Bas-Belleville in the nineteenth, gives increased recognition to the name of Belleville and a boost in numbers to its population.

If Belleville, according to the 1891 Census figures, had the reputation of being the most Parisian of quartiers (Jacquemet 1984: 393), this was no longer the case a century later. Provincial migration occurred first towards the end of the nineteenth century, primarily from the central region of Auvergne. Foreign immigration took place throughout the twentieth century, beginning with the Ashkenazi Jews from Eastern Europe escaping pogroms in their homelands. Their arrival and subsequent transition from persecuted 
victims to respected artisans in the clothing and shoe industries can be linked to the construction of a new identity: for themselves, with the quartier into which they were welcomed, and for Belleville itself, which assumed an Ashkenazi Jewish identity that was to remain valid until the 1950s. Armenians, Greeks and Polish Jews continued to migrate throughout the interwar years. Following the deportation and decimation of the Jewish population of Belleville during World War II, the French government's proimmigration policy led to the arrival of large numbers of Sephardic Jews and Muslims from the former colonies of the Maghreb. Immigration to the quartier continued in waves throughout the 1960s, with the first sub-Saharan Africans contributing to the increasingly cosmopolitan population. Refugees from Asia were the next to arrive. The first wave came from China throughout the 1960s and 1970s, and those arrivals were joined in the 1980s by South-East Asians. With the Asian influx towards the end of the twentieth century, the Bellevillois population took a geographic and cultural turn far removed from its European, and then African, heritage.

A century of immigration has transformed the face of Belleville from the most Parisian of quartiers to a multicultural district with a significantly higher percentage of residents of immigrant origin, and a proportion of non-European residents, which at eighteen percent is twice the Parisian average (Clerval, Fleury \& Humain-Lamoure 2011: 53). It is, however, not only the cultural face of the quartier that has been transformed over the last century. Belleville’s physical metamorphosis is also evidenced by the mosaic of building styles, the legacy of 150 years of urban planning and renovation.

Each of the stages of urban renovation that occurred spasmodically and belatedly in Belleville brought about significant demographic change. Firstly, amongst the flow-on effects of Baron Haussmann's extensive reforms to the French capital in the 1860s was an exodus of the poorer residents of inner Paris to the outskirts of the capital, including the newly annexed Belleville. The quartier thus assumed an enduring working-class populaire identity. Substandard housing erected throughout the latter half of the nineteenth century to cater for the growing population was poorly maintained, with construction and renovation at a standstill at the end of the century. Despite a recognized urgent need at the beginning of the twentieth century to prioritize Belleville's insalubrious and unstable structures, no renovations of note took place until the 1960s; this heralded the second stage of the quartier's urban transformation. Three 
sectors previously designated as insalubrious were completely razed, signalling the end of the populaire atmosphere that had existed in Belleville for a century.

Under Jacques Chirac’s mayorship of Paris (1977-1995), the third stage comprising an extensive makeover of the East of the French capital was initiated in the 1980s, and the overhaul of Belleville continued. If Chirac’s renovations were generally less radical than those of the 1960s and 1970s, some buildings were considered beyond salvation, and replaced with apartment blocks considered by many to be unsightly. In the mid1990s Belleville’s residents demonstrated their recalcitrant streak by persuading the government to take a less dramatic approach to the quartier's renovation. The final stage in Belleville's transformation thus began with the soft urbanism promoted by Antoine Grumbach that had been successfully implemented in other Parisian quartiers (Yaari 2008: 276). This stage is still underway, and coincides with a progressive gentrification of parts of Belleville that is already affecting the social composition of the quartier's population. Simon names the group of mainly middle-class residents whose move into the quartier is linked to the gentrification process multiculturels; the motives behind their choice of Belleville as residence are both financial and ideological (1994: 446). A slightly smaller group of new residents whom Simon calls transplantés are similarly middle-class, but driven more by the cheaper accommodation available than by the desire to live in a cosmopolitan quartier (1995: 185). In a century and a half, Belleville has thus been transformed from an impoverished quartier populaire on the outskirts of Paris to a partially gentrified inner-Parisian quartier. This transformation has necessarily impacted the quartier's image viewed both from inside, by its population in constant metamorphosis, and from outside, by literary and social commentators with an interest in Belleville.

The geographical, historical, cultural and social features of Belleville are variously represented in non-fiction, literature and popular culture. By classifying these representations as rouge, noir or rose, we can establish several identities that pertain to the quartier and its inhabitants. ${ }^{5}$ Some works fall easily into one or other category, whilst others, such as the Malaussène series by Daniel Pennac-Au Bonheur des ogres

\footnotetext{
${ }^{5}$ I explored extensively this categorisation in my doctoral thesis, Belleville rouge, Belleville noir, Belleville rose: Représentations d'un quartier parisien depuis le Moyen Âge jusqu'à l'an 2000 (Stott 2009).
} 
(1985); La Fée carabine (1987); La Petite Marchande de prose (1989); and Monsieur Malaussène (1995)—are more difficult to classify.

\section{Belleville rouge}

History and politics merge in the association of the colour red with Belleville. The blood shed in defence of the quartier from the beginning of the Second Empire (1852) is testimony to the revolutionary tendencies of the inhabitants. With a high proportion of manual labourers and craftsmen possessing a strong sense of social justice, sometimes to the point of anarchy (Braquet: 23), the Bellevillois population played an active role in the Commune of 1871. The capitulation of Belleville in the final battle of the Semaine sanglante (Bloody Week) signalled the end of the Commune. Journalist, author and politician Jules Vallès recounts in detail the quartier's role in the insurrection in L'Insurgé (1886), as does Émile Zola in La Débâcle (1892). In the wake of the Commune, the first cooperative in France was established in Belleville in 1877 with the aim of giving the quartier's working-class inhabitants access to political education and culture. On the eve of World War I, with a membership of 9,000 and an additional focus on equitable commerce, La Bellevilloise had become a model for subsequent cooperatives in Paris and throughout France, and played a major role in the economic and cultural life of Eastern Paris until the 1950s (Lafon 2011). Its impact on the population of Belleville was such that the Cooperative's name was deliberately associated with a major struggle to preserve the history and character of the quartier towards the end of the twentieth century.

The enduring streak of rebellion and social justice that characterised the Bellevillois inhabitants in the nineteenth century was evident one hundred years later in the creation of the Association La Bellevilleuse. Inhabitants of Bas-Belleville (Lower Belleville) mobilised in the 1980s to fight a plan to completely demolish the sector. The Association was created to provide support for inhabitants whose residences were under threat and who were mostly of working-class and/or immigrant origin, and lacking the necessary expertise to fight the powerful government-led redevelopment project. Support was offered in the form of legal counsel, business, financial and construction advice. A protracted David and Goliath-inspired battle ended in victory for the inhabitants, with 22 percent of buildings demolished instead of the 95 percent initially targeted by the government. The Association La Bellevilleuse's struggle and subsequent 
triumph is mirrored throughout the last tome of Pennac's Malaussène series (Monsieur Malaussène 1995), in which the fictional residents of Belleville demonstrate their recalcitrance by banding together to save the Zèbre cinema from demolition. ${ }^{6}$ Literary commentator David Platten refers to Pennac’s deliberate attempts to portray his Belleville-based characters as belonging to 'a mildly anarchic, alternative society ... which ferociously resists institutional meddling in its affairs' (Platten 2011: 183) and the imposition of 'bourgeois codes of morality' (188). Possessed of a strong moral code, Pennac's Bellevillois characters are liberally tinged with red: they stand up for immigration and peaceful cohabitation and against racism, political and police corruption, exploitation of the disadvantaged; they defend the physical environment in which they live, along with its history.

Belleville's association with the colour red is evident in its inhabitants' past and present struggles, in their politics, passion and courage to stand up for what is right and in the blood shed in this process. Noir author Patrick Pécherot recalls this tradition through the setting of Belleville-Barcelone (1938 Paris, the dying days of the Front populaire in the face of a rising fascist movement) and in the words of his detective protagonist: 'The quartier's colour tended towards red' (Pécherot 2003: 127). If the bloodshed during the violent insurrections of the past is more figurative in relation to contemporary struggles in Belleville, the quartier's association with corruption and crime is, however, still a reality, revealing the dark side of Belleville’s identity.

\section{Belleville noir}

Belleville's association with violence and crime can be traced back to the middle of the fifteenth century, when the gallows of Paris were transferred to a part of what is now Belleville called Montfaucon, where they remained until the eighteenth century. Poet François Villon's Testament (1461) and Ballade des pendus (1462) evoke the curious crowds drawn to Montfaucon to witness murderers and criminals meet their end.

Belleville is evoked in literature as a quartier of ill repute from the eighteenth century, with contraband transactions around the Mur des Fermiers Généraux, sleazy activity in the vicinity of the gypsum quarries of the Buttes Chaumont in the nineteenth century

\footnotetext{
${ }^{6}$ In reality, the last remaining cinema in Belleville called the Berry-Zèbre found itself in a similar situation at the end of the 1980, and was saved by proaction on the part of the Bellevillois population. I have argued elsewhere that the publication of Monsieur Malaussène helped resurrect the cinema as the Zèbre cabaret-cirque performance space in 2003 (Stott 2009: 266).
} 
and the presence of the hoodlum apaches during the Belle Époque. Historian John Merriman claims that nineteenth century Belleville housed 'the very worst people of the capital and the most turbulent of workers from the faubourgs [outskirts]' (1991: 203). Contemporary Belleville reflects this heritage, with its reputation as a centre of illegal activities depicted frequently in roman and film noir in the second half of the twentieth century, this despite the reality that the quartier's crime figures are amongst the lowest in the French capital (INHESJ/ONDRP 2013). Racial tension is evident from time to time, most recently in the victimization of the Asian community, ${ }^{7}$ who are often perceived as insular by parts of the Bellevillois population. The quartier's standing as a dangerous space and hive of criminal activity is, however, heightened by its frequent negative depiction in contemporary literature and popular culture. Literary commentator Moez Lahmédi describes the quartier as 'morbid ... an archetypal crime fiction topos' (2011: 5).

Many of these contemporary noir representations can be grouped in the May 1968inspired genre of the néo-polar, whose themes denounce destructive aspects of contemporary French society such as racism, corruption, unemployment and its consequences. From Flic Story by Jacques Deray (1975) to L.627 by Bertrand Tavernier (1992), Belleville was portrayed nine times in film and many more in literature as a centre of vice (Stott 2009). Néo-polar authors and residents Joseph Bialot, Thierry Jonquet and Serge Quadruppani repeatedly paint their quartier as demoralizing, decrepit and sinister; their representations are validated by allusions in their texts to historical facts associating contemporary Belleville with its past, and verified by the reality of some pockets of the quartier, where the all-too-evident repercussions of unemployment, such as poverty and delinquency, abound. For Bialot, geographical landmarks such as the Père Lachaise cemetery are the root of Belleville's evil, and to be avoided at all costs; a wrong turn into the cemetery leads to murder in Babel-ville (1979). Throughout his Belleville series (1993, 1994, 1998), Jonquet focusses on the prevalence in the quartier of racial tension, delinquency and marginalization, gloomily foreseeing Belleville’s ultimate demise. Negative undertones relating to Belleville’s shady past and present are present in Quadruppani’s Belleville series and short stories (1991, 1992, 1994, 1996). La Forcenée, for example, alludes to the recent architectural history of the

\footnotetext{
${ }^{7}$ A peaceful protest by the Chinese community of Belleville in June 2010 degenerated into violence with the involvement of non-Chinese youth, allegedly from both inside and outside the quartier.
} 
quartier through his squatter protagonists' protest against the property development in Eastern Paris (1994: 36). Pécherot returns to the Paris populaire of the 1930s, implicating the quartier in multiple murders, Russian arms deals, the demise of the Front populaire and the rise of the extreme-right movement La Cagoule (2003). Resident, author and film director Arnaud Malherbe nominates Belleville as both title and décor for his tele-film (2010) and two-volume graphic novel (Malherbe \& Perriot 2010) in a deliberately archetypal noir depiction of the quartier, with twenty-first century themes of illegal immigration and the Chinese mafia. Pennac, too, takes up classic noir themes such as racism (1987), corruption (1987, 1989), occultism (1985), murder and violence. Nor can he ignore Belleville’s state of significant disrepair. Throughout his Malaussène series he refers to the progressive disappearance of 'his' Belleville of yesteryear, facilitated by corrupt property developers; as a former longterm resident in the latter part of the twentieth century, he is well placed to give evidence. Crime thus remains commonplace in the Belleville of the néo-polar genre, far more so than occurs in reality in the quartier, and often more grisly in nature. The colour black is thus closely associated with Belleville's dark past and present. However, if the quartier appears in print and in celluloid as architecturally and morally doomed, more than a hint of rose appears in fiction and in reality, as writers and residents focus on the pleasures and amusements to be found in its domains.

\section{Belleville rose}

If the colour pink is synonymous with amorous endeavours and the pursuit of pleasure, Belleville's history and representations in literature and popular culture are laden with examples. Jean-Jacques Rousseau admired the solitary delights of the 'joyful countryside' in the late eighteenth century (1782: 14-15). His more sociable countrymen of all classes preferred the crowds of the cabarets of La Courtille. The famous Descente de la Courtille parade which took place every year until 1838 as part of the Mardi Gras festival is evoked by Edmond and Jules Goncourt (1856), and the appropriately named Place des Fêtes, created in 1836, was the site of many open-air balls. The pleasures of the quartier populaire as it existed in the first half of the twentieth century were variously vaunted in song by Edith Piaf (Rivgauche \& Léveillée 1960) and Maurice Chevalier (1942); on paper by Jacques Prévert (as scriptwriter for Marcel Carné's Enfants du paradis in 1945) and Eugène Dabit (1933: 90); and in film, most notably by Albert Lamorisse (1956). 
With the focus during the second half of the twentieth century on the physical transformation of the quartier and the progressively changing face of its population, writers and social commentators observed a gradual move away from the traditional image of the Parisian quartier populaire. The association of the colour pink with optimism and a sense of nostalgia for the past is variously made by literary and social commentators of contemporary Belleville, who see the quartier as one of the last remaining vestiges of Paris populaire. In the works of writers and former Belleville residents Romain Gary and Daniel Pennac, a positive representation overrides less salubrious themes. Gary's depiction of the quartier as a warm cosmopolitan community is amusing, sincere and undoubtedly coloured by his own memories of a newly arrived, impoverished young immigrant in 1928 (1975). In the Malaussène series, Pennac's protagonists are nourished, sheltered and protected by a close-knit circle of friends who replace absent family members and whose diverse nationalities accurately reflect the multicultural population of Belleville: the Ben Tayed family who appear throughout the series hail from Algeria; Loussa de Casamance, the Mandarin-speaking colleague of Benjamin is from Sénégal (1989); Stojilkovitch is from Serbia (1985); and Van Thian is from Vietnam (1987).

It is little wonder that Pennac, in an interview with the author in 1998, described the quartier in which he lived for many years as a 'miniature planet ... a multinational community.' Given their often precarious existence prior to moving to Belleville, and the relatively warm welcome that they receive in the quartier from neighbours with whom they might share a religion, culture, nationality, history or values, residents of immigrant origins often develop a deep attachment to Belleville. ${ }^{8}$ Platten suggests that Pennac invents for his characters complex past histories relevant to Belleville’s history, and integrates them into the plot in an attempt to establish a 'communal identity' (2011: 183); his characters' identification with the quartier is strong, and the support shown for their neighbours unyielding, especially in the face of adversity. The Bellevillois inhabitants demonstrate a similar communal identity in real life, according to Simon, who cites in support of this argument the relative stability of the immigrant population (1992: 54). Local residents confirm the on-going existence of a strong collective Bellevillois identity, despite signs of deterioration (Rigoulet: 2010). Members of

\footnotetext{
${ }^{8}$ Pécherot confirms the deep-seated loyalty felt towards Belleville by one of his immigrant characters who resides in the quartier in Belleville-Barcelone (2003: 71).
} 
different nationalities accept the different cultural and religious practices of their neighbours and manage to share the restricted physical space in relative harmony. Festivals and exhibitions are commonplace, and the number of associations created to support the residents of Belleville is three times that of the average across Paris (APUR 2007: 130). ${ }^{9}$ Rather than a ghetto, Belleville is a cultural melting pot whose members might shop in different sectors yet live in the same apartment building. They plant together and share the products of community gardens; they exchange culinary skills for computing expertise in community centres (De Villanova 2011: 193). The community spirit that is a sign of a strong communal identity with the quartier is continuously evoked by Pennac; the local youths with an intimidating air follow an elderly Vietnamese resident from the ATM where she has withdrawn a large sum of money not with the intention of robbing her, but of assuring her safety (1987: 29-31). Cissou, the council locksmith with an acute sense of social justice, coordinates by day the forced eviction of local inhabitants behind in their rent, and by night returns the belongings he has just confiscated to their owners (1995).

Pennac's Belleville, despite its crumbling physical appearance, has a lively sense of community reminiscent of the Paris populaire of a long-gone era. If his representation of Belleville as a uniquely enduring haven of social harmony is perceived by some commentators as utopian, Simon and Tapia underline the sense of tolerance that prevails in reality, and explain the relative harmony in the quartier by the observation on the part of Bellevillois inhabitants of the golden rule of peaceful coexistence: keeping a respectful distance (1998: 101). The quartier as it is represented in the Malaussène series is certainly idealistic, but it is a resident author's personal perspective, tinged heavily with the pink of nostalgia, as is the Belleville of Gary, Lamorisse, Dabit, Piaf and others. Readers are offered a set of rose-coloured glasses and a glimpse of what the quartier might once have been and what it could be again. The prevalence in literature, sociology and popular culture of this idealistic vision is sufficient to engender widespread belief and perpetuate the image in reality, as evidenced by the overriding sense of community and tolerance for other cultural practices that is highly unusual in a multiethnic quartier such as Belleville.

\footnotetext{
${ }^{9}$ Roselyne de Villanova notes that the aim of many of these associations is to provide assistance to those in need (often of immigrant origin), whilst at the same time encouraging independence and ultimately a smoother integration into the quartier (2011: 193).
} 
Pennac’s Malaussène series defies classification as mere rose-coloured nostalgia: like Belleville itself, it blends all three elements, rose, rouge, noir, into the creation of a collective Bellevillois identity, according the quartier the status of central character. Indeed, classifying the series as part of a single literary genre is similarly problematic; it contains elements of detective fiction, fairy tale, myth and reality. This diversity has no doubt contributed to its broad appeal and consequent remarkable success. These elements continue to mark the most recent representations of Belleville. Author and film director Xabi Molia, like Pennac, incorporates elements of noir, rouge and rose in his futuristic depiction of a dilapidated twenty-first century Belleville caught in the grip of an epidemic, against which the uninfected fight desperately for survival (2011); the doctor protagonist responsible for tracking the spread of the epidemic discovers a longlost love for his missing wife along the way.

\section{Conclusion}

These three strands_rouge, noir and rose - that run through the literary, historical, sociological and cultural representations of Belleville, have been woven together over time to create a rich, complex, multi-layered ‘imagined community’ (Anderson 1991). There is a certain continuity in the themes that persist over the centuries, and yet each era brings reinterpretation and modification of this legacy. Myth and reality have become inextricably interwoven as the very reputation of the quartier inspires new generations to assume the mantle of its past. Thus the memory of working-class activism and cooperation characteristic of the late nineteenth century is incorporated into the battle to save Bas-Belleville from property developers by the determined group of inhabitants who founded the Association La Bellevilleuse in the 1990s. We may speculate that the vibrancy of the community of Belleville today results in part from its reputation, taken up and defended by contemporary residents: the multiculturels, the writers and artists, the immigrants anxious to leave the conflicts of their past lives behind them and contribute to a tolerant, diverse community. We may speculate, too, that Pennac's exploitation of the political and cultural history of Belleville and the idealisation of the sense of community associated with the quartier have resonated with an audience concerned about the future of the cities in which they live. Readers of the Malaussène series are reminded of the importance of identifying with and preserving the history and values of public spaces. 
Pennac's representation of Belleville evokes the much broader concept of French cultural memory defined by Pierre Nora, for whom a place’s changing physical appearance matters less than the memory that survives it. According to Nora, this memory relies heavily upon those who retain it, and as such is in a state of perpetual evolution (1997: 24). In applying Nora's concept of cultural memory to Belleville, the physical boundaries of the quartier become less important than the resonance of the events that take place there in the memory of the residents. Pennac can thus be seen as guardian of Belleville's cultural memory; his notion of geography surrendering to history in Belleville (1989: 401) holds true. And yet perhaps the key to Belleville's unique status and complex identity is, in fact, its geographical location. Originally situated beyond the physical boundaries of Paris, it was not obliged to answer to the city's authorities and thus acquired its reputation for rebellious behaviour, contraband activities and illicit pleasures. Even since its annexation to Paris, Belleville has continued to function as an extraordinary space where it is customary to expect the unexpected. This, too, is reflected in Pennac's Malassène series, in the characters who reside in the quartier and in the quartier itself: 'What I love about Belleville is the element of surprise’ (Pennac 1987: 262).

\section{Reference List}

Anderson, B. 1991, Imagined Communities: Reflections on the Origin and Spread of Nationalism, 2nd ed. Verso, London.

Atelier parisien d’Urbanisme (APUR). 2007, Contrat Urbain de cohésion sociale pour Paris 2007-2009 [Urban Contract for Social Cohesion in Paris 2007-2009], 14 February. Online, available: http://www.apur.org/cdrom/CD_CUCS_2010/pdf/menu4_publications/Le percent20contenu percent20du percent20CUCS percent20de percent20Paris.pdf [Accessed 6 August 2013].

Augé, M. 1995, Non-places: Introduction to an Anthropology of Super Modernity. Verso, London \& New York.

Bialot, J. 1979, Babel-ville [City of Babel]. Gallimard, Paris.

Braquet, M. 2003, 'Petits gars pas tranquilles à Belleville [Little Troublemakers in Belleville]', Quartiers libres, no. 94-95 (automne-hiver): 23-24.

Carnet, M. (dir.) 1945, Les Enfants du paradis [The Children of Paradise]. Feature film, Pathé, Paris.

Chevalier, M. \& Vandair, M. 1960, La Marche de Ménilmontant [Ode to Menilmont]. Song.

Clerval, A., Fleury, A. \& Humain-Lamoure, A.-L. 2011, 'Belleville, un quartier parisien [Belleville, a Parisian quartier]', in Belleville, quartier populaire? [Belleville, a Popular quartier?] (eds) R. De Villanova \& A. Deboulet. Créaphis, Paris: 51-63.

Dabit, E.1990 [1933]), Faubourgs de Paris [Parisian Suburbs]. Gallimard, Paris.

De Villanova, R. 2011, 'Belleville, créativités et démocratie locale? [Belleville, Creativity and Local Democracy?], in Belleville, quartier populaire? (eds) R. De Villanova \& A. Deboulet. Créaphis, Paris: 185-199.

Gary, R. (signed Ajar Émile). 1975, La Vie devant soi [The Life Before Us]. Mercure de France, Paris. Goncourt, E. \& Goncourt, J. de. 1856, Une Voiture de masques [A Coach of Masks]. E. Dentu, Paris. Jacquemet, G. 1984, Belleville au XIX ${ }^{e}$ siècle: du faubourg à la ville [Belleville in the Nineteenth Century: From Regional District to City Suburb]. Éditions de l’École des Hautes Études en Sciences Sociales, Paris. 
Jenkins, R. 2006, Social Identity, 2nd ed. Routledge, London \& New York.

Jonquet, T. 1993, Les Orpailleurs [The Gold Panners]. Gallimard collection Série noire, Paris.

Jonquet, T. 1994, La Vie de ma mère [On My Mother’s Life]. Gallimard collection Folio, Paris.

Jonquet, T. 1998, Moloch. (Thorny Dragon). Gallimard collection Folio policier, Paris.

Jonquet, T. 2003, Jours tranquilles à Belleville [Peaceful Days in Belleville]. Seuil, Paris.

Kupferman, P/ 2013, 'Où trouver les loyers les moins chers de Paris?,' [Where to Find the Cheapest Rent in Paris ?], Challenges. Online, available: http://www.challenges.fr/actuimmo/20130204.CHA5853/ou-trouver-les-loyers-les-moins-chers-de-paris.html [Accessed 13 August 2013].

Lafon, C. 2011, 'Notre histoire [Our History]', La Bellevilloise. Online, available: http://www.labellevilloise.com/notre-histoire/ [Accessed 1 June 2013].

Lahmédi, M. 2011,'Représentation de l’espace urbain dans la série Malaussène de Daniel Pennac [Representation of Urban Space in Daniel Pennac's Malaussène Series], Le Rayon du polar. Online, available: http://www.rayonpolar.com/Dossiers/article/49.pdf [Accessed 2 August 2013].

Lamorisse, A. (dir.) 1956, Le Ballon rouge [The Red Balloon]. Feature film, Films Montsouris, Paris.

'Les Crimes et délits enregistrés à Paris en 2012 [Crimes and delinquency reported in Paris in 2012]' 2013, INHESJ/ONDRP Rapport. Online, available:

http://www.inhesj.fr/sites/default/files/files/ondrp_ra-2013/03_DII_Grand_Paris_Crimes_delits.pdf [Accessed 8 August 2014].

Malherbe, A. 2010, Belleville Story. Tele-film, 26 February, Arte, France.

Malherbe, A. \& Perriot, V. 2010, Belleville Story Avant minuit [Before Midnight]. vol. 1, Dargaud, Paris.

Malherbe, A. \& Perriot, V. 2011, Belleville Story Après minuit [After Midnight]. vol. 2, Dargaud, Paris.

Merriman, J. 1991, The Margins of City Life. Oxford University Press, New York. doi: http://dx.doi.org/10.1093/acprof:oso/9780195064384.001.0001.

Molia, X. 2011, Avant de disparaître [Before Disappearing]. Seuil, Paris.

Nora, P. 1997, Lieux de mémoire [Realms of Memory]. Tome 1. Gallimard collection Quarto, Paris.

Pécherot, P. 2003, Belleville-Barcelone, Gallimard, Paris.

Pennac, D. 1985, Au Bonheur des ogres [The Scapegoat]. Gallimard, Paris.

Pennac, D. 1987, La Fée carabine [The Fairy Gunmother]. Gallimard, Paris.

Pennac, D. 1989, La Petite Marchande de prose [Write to Kill]. Gallimard, Paris.

Pennac, D. 1995, Monsieur Malaussène [Mr Malaussène]. Gallimard, Paris.

Platten, D. 2011, The Pleasures of Crime: Reading Modern French Crime Fiction. Rodopi, Amsterdam \& New York.

Quadruppani, S. 1991, Y (There). Métailié, Paris.

Quadruppani, S. 1992, Rue de la Cloche [Bell Street]. Métailié, Paris.

Quadruppani, S. 1994, La Forcenée [The Madwoman]. Métailié, Paris.

Quadruppani, S. 1996, 'La Montée de la Courtille [The Ascent of La Courtille]', in Paris, rive noire, (The Dark Side of Paris), (ed.) H. Dougier. Autrement collection Romans d'une ville, Paris: 5-34.

Rigoulet, L. 2010, 'Casse-tête à Belleville [Belleville Conundrum],' Télérama.fr, no. 3179-3180. Online, available: http://www.telerama.fr/monde/casse-tete-a-belleville,63726.php [Accessed 9 August 2013].

Rivgauche, Michel \& Léveillée, Claude. 1960, Boulevard du crime [Crime Boulevard]. Song.

Rousseau, J.-J. 1960 (1782), Rêveries d'un promeneur solitaire [Daydreams of a Solitary Rambler]. Garnier-Frères, Paris.

Simon, P. 1992, 'Belleville, un quartier d’intégration,’ Migrations Société, vol. 4, no. 19 (janvier-février): 45-68.

Simon, P. 1994 'L'Esprit des Lieux' [Sense of Place], in in Belleville, Belleville, visages d'une planète [Belleville, Belleville, Faces of a Planet], (ed.) F. Morier. Créaphis, Paris: 428-457.

Simon, P. 1995 'La Société partagée. Relations interethniques et interclasses dans un quartier en rénovation. Belleville, Paris $\mathrm{XX}^{\mathrm{e}}$ [Shared Society. Interracial and Interclass Relationships in a Changing quartier], Cahiers internationaux de sociologie, vol. 98: 161-190.

Simon, P. \& Tapia, C. 1998, Le Belleville des Juifs tunisiens [The Tunisian Jews of Belleville]. Éditions Autrement, Paris.

Stott, C. 2009, Belleville rouge, Belleville noir, Belleville rose: Représentations d'un quartier parisien depuis le Moyen Âge jusqu'à l'an 2000 [Red Belleville, Black Belleville, Pink Belleville:

Representations of a Parisian Neighbourhood from the Middle Ages to 2000]. Doctoral thesis, completed under the supervision of Professor Jean Fornasiero, University of Adelaide. Online, available http://hdl.handle.net/2440/50422 [Accessed 9 August 2013]. 
Stott, C. 2011, 'Belleville au pluriel: Representations of a Parisian Suburb in the Néo-polar,' in Hexagonal Variations. Diversity, Plurality and Reinvention in Contemporary France, (eds) J. McCormack, M. Pratt, A. Rolls. Rodopi, Amsterdam \& New York: 355-370.

Vallès, J. 1975 (1886), L'Insurgé [The Insurgent]. Gallimard collection Folio classique, Paris.

Villon, F. 1991 (1461-1462), Poésies complètes [Complete Poetry], (ed.) M. Zink. Le Livre de Poche collection Lettres gothiques, Paris.

Yaari, M. 2008, Rethinking the French City: Architecture, Dwelling and Display after 1968. Rodopi, Amsterdam \& New York.

Zola, É. 1892, La Débâcle [The Debacle]. G. Charpentier, Paris. 